\title{
ERBB2 Exon 20 Mutation
}

National Cancer Institute

\section{Source}

National Cancer Institute. ERBB2 Exon 20 Mutation. NCI Thesaurus. Code C150632.

A molecular genetic abnormality indicating the presence of a mutation in exon 20 of the ERBB2 gene. 